\title{
Examining L1 Brazilian Portuguese speakers' sensitivity to English nuclear stress assignment ${ }^{1}$
}

\section{Examinando a sensibilidade dos falantes brasileiros à alocação do acento nuclear do inglês}

\author{
Hanna Kivistö-de Souza \\ Universidade de Barcelona \\ hanna.kivistodesouza@gmail.com
}

\begin{abstract}
The aim of this paper was to examine whether Brazilian Portuguese learners of English are aware of English nuclear stress assignment and whether this awareness is affected by the utterance type. To the date, little research has been carried out about the acquisition of English suprasegmentals by Brazilian Portuguese speakers. Previous studies indicate that the acquisition of target-like nuclear stress assignment is difficult for EFL learners (ZUBIZARRETA; NAVA, 2011). However, non-target-like nuclear stress assignment is likely to lead into communication breakdowns, making its mastering a priority for L2 learners. The participants were 69 L1 Brazilian Portuguese learners of English and 16 native English speakers. Sensitivity to L2 prosody was measured in a perception task which presented low-pass filtered utterances differing in nuclear stress assignment. The results showed that the L1 Brazilian Portuguese speakers possessed less awareness about
\end{abstract}

\footnotetext{
${ }^{1}$ The research reported in this manuscript is based on the doctoral research project of the author in which Brazilian Portuguese EFL learners' awareness about English phonology was examined in the segmental, phonotactic and suprasegmental domains (KIVISTÖ-DE SOUZA, 2015). The manuscripts reports only on the results of the prosodic domain, whose data was re-analyzed for the purposes of this paper.
} 
English nuclear stress assignment than the native English speakers $(F(1$, $\left.83)=55.95, p<.001, \eta^{2}=.40\right)$. Furthermore, awareness was affected by utterance type so that the only test category manifesting above chancelevel performance was deaccented sentences ending in function words $(76 \%)$. In unaccusative (40\%) and deaccented utterances ending in given information $(52 \%)$, the performance was at or below chance-level. The findings suggest that L1 Brazilian Portuguese learners would benefit from explicit prosodic instruction even at advanced levels of proficiency.

Keywords: phonological awareness; prosody; pronunciation.

Resumo: O objetivo deste artigo foi examinar se os aprendizes brasileiros de inglês têm consciência sobre a alocação do acento nuclear de inglês, e se esta é afetada pelo tipo de sentença. Atualmente, poucos estudos têm sido conduzidos sobre a aquisição suprassegmental do inglês por falantes brasileiros. Os estudos prévios mostram que a aquisição de acento nuclear é difícil para aprendizes de inglês (ZUBIZARRETA; NAVA, 2011). No entanto, o uso adequado do acento nuclear deve ser uma prioridade para aprendizes de LE porque o seu uso inadequado leva a mal-entendidos. Os participantes foram 69 aprendizes brasileiros de inglês e 16 falantes nativos de inglês. A sensibilidade ao acento nuclear na LE foi medida num teste de percepção que apresentou sentenças com filtro passa-baixa que variavam nos padrões de entoação. Os resultados mostraram que os aprendizes brasileiros de inglês manifestavam uma sensibilidade mais baixa ao acento nuclear de inglês que os falantes nativos de inglês $\left(F(1,83)=55.95, p<.001, \eta^{2}=.40\right)$. Além do mais, a sensibilidade variava em função do tipo de sentença, de tal maneira que somente as orações que terminavam em categorias funcionais $(76 \%)$ mostravam desempenho acima do nível estatisticamente esperado ao acaso. Nas orações inacusativas $(40 \%)$ e desacentuadas terminadas em informação dada (52\%), o desempenho estava abaixo ou no nível estatisticamente esperado ao acaso. Os resultados sugerem que instrução explícita sobre a prosódia de L2 seria benéfica inclusive aos aprendizes brasileiros de inglês com um nível avançado de proficiência.

Palavras-chave: consciência fonológica; prosódia; pronúncia.

Recebido em: 14 de maio de 2016. Aprovado em: 23 de junho de 2016. 


\section{Introduction}

Children show sensitivity to first language (L1) prosody from 8-months of age onwards (JOHNSON; JUSCZYK, 2001). This sensitivity to prosody is maintained over lifetime, as adult language users are able to distinguish questions and exclamations from statements, as well as to interpret the speaker's intentionality from the literal meaning of the utterance. Moreover, speakers are able to produce a wide variety of rhythmic and intonation patterns. How this sensitivity to prosody is manifested in second language (L2) learners is the focus in the present study. Whereas native speakers' phonology is a stable system in which perception and production errors rarely occur, non-native speakers' interlanguage system is incomplete and unstable. The acquisition of targetlike nuclear stress assignment has been shown to be especially challenging for native speakers of Romance languages learning English (e.g., NAVA, 2008). Romance and Germanic languages differ in the rules governing nuclear stress assignment, which leads to misunderstandings in perception and production when communicating in the L2. These acquisition problems persist even at advanced stages of L2 learning (ZUBIZARRETA; NAVA, 2011), for which the subject is especially relevant.

Little research has been carried out about the acquisition of English prosody by L1 Brazilian Portuguese speakers as most studies have focused on the acquisition of the segmental domain (e.g., ALVES; ZIMMER, 2015; CRISTÓFARO SILVA;CAMARGOS, 2016; KLUGE, 2012; RAUBER, 2006; SILVEIRA, 2012). In L2 prosodic acquisition, the employment of consciousness-raising activities has been shown to be helpful for EFL learners (RAMÍREZ VERDUGO, 2006; SAITO; WU, 2014). Previous studies on L2 prosodic awareness have employed mainly explicit testing methods for language learners undergoing an instructional period in L2 prosody (e.g., KENNEDY, BLANCHET; TROFIMOVICH, 2014; RAMÍREZ VERDUGO, 2006). Nevertheless, most of the language learners have never attended a specialized course in L2 phonetics. For this reason, examining language learners during a phonetic training period might not be representative of L2 learners as a whole. The present study sought to remedy these gaps in literature by examining phonetically naïve language learners' awareness about L2 nuclear stress assignment with implicit testing methods. Employing implicit tests rather than asking the participants to verbally report on 
their awareness is more suitable as the majority of the language users are unable to verbalize and elaborate on rules about L1 and L2 phonology.

The aim of the present paper was to examine to which extent Brazilian Portuguese ELF learners are aware of L2 prosody, more specifically, nuclear stress assignment, and whether this awareness would be affected by the utterance type (unaccusative/deaccented). The paper begins with a short review of relevant L1 and L2 literature and then presents the methodology and results of the study. Finally, the results are contrasted with previous findings from the area and discussed from a pedagogical perspective.

\section{Review of literature}

\subsection{Prosodic awareness research in the first and the second language}

The majority of studies within L1 phonological awareness have focused on explicit measures examining children's ability to segment and manipulate phones, onsets and rimes. Nevertheless, children's awareness about the prosody of the L1 has also been under investigation in a small number of studies (e.g., DEFIOR, GUTIÉRREZ-PALMA; CANOMARÍN, 2012; GOODMAN; LIBENSON; WADE-WOOLLEY, 2010; HOLLIMAN; WOOD; SHEENY, 2008). L1 prosodic awareness, contrary to L1 phonemic awareness, is not evident in conscious manipulation of speech segments, but in sensitivity to acceptable and unacceptable L1 prosodic patterns (LANCE; SWANSON; PETERSON, 1997), and in the accurate production and perception of these patterns (GOODMAN et al., 2010). Contrary to L1 phonemic awareness which develops through contact with L1 script (TARONE; BIGELOW, 2007), L1 prosodic awareness develops spontaneously through language contact, and infants have been shown to gain sensitivity to L1 prosody from eight months of age onwards (JOHNSON; JUSCZYK, 2001).

Several areas within prosody have been examined under L1 prosodic awareness: speech rhythm (WOOD; TERRELL, 1998), nonspeech rhythm (WHALLEY; HANSEN, 2006), phrasal stress assignment (WHALLEY; HANSEN, 2006; WOOD; TERRELL, 1998) and word stress (eg., DEFIOR et al., 2012). The tasks employed in these studies can be characterized as measuring implicit, rather than explicit awareness, as children are not asked to manipulate on speech stimuli or verbalize 
any knowledge, contrary to traditional phonological awareness studies. The tasks have mainly focused on speech perception and have presented unaltered or altered speech (speeded up, low-pass filtered) in which the children's task has been to identify, discriminate or match the auditory samples. For example, in a rhythmic matching task (WOOD; TERRELL, 1998), children were presented with a low-pass filtered utterance and two normal, unaltered utterances conserving all auditory cues. The children had to select from the unaltered utterances the one that corresponded to the low-pass filtered one.

Findings from L1 prosodic awareness research suggest that it is related to word and nonword reading (e.g., DEFIOR et al., 2012; GUTIÉRREZ-PALMA; PALMA-REYES, 2007). Nevertheless, the variance accounted by L1 prosodic awareness seems to be small after explicit L1 phonological awareness has been accounted for (HOLLIMAN et al., 2008). Prosodic awareness might also be related to L1 phonemic and rime-onset awareness (HOLLIMAN et al., 2008), although some studies have not found a relation between the two (DEFIOR et al., 2012). More research on L1 prosodic awareness is required to understand its relation to L1 phonemic awareness and to learner variables such as cognitive resources and contact to foreign languages, for example.

In SLA, research on phonological awareness, and more specifically on prosodic awareness, has been scarce. Only a handful of studies have examined language learners' knowledge about different suprasegmental aspects of the L2. Most of the studies about L2 prosodic awareness have been carried out by Kennedy and her colleagues in Montréal. Kennedy and Trofimovich (2010) introduced journal writing as a tool to follow English as a second language learners' awareness about aspects of L2 prosody during a pronunciation course focusing on suprasegmentals. The journal entries were assessed for quantitative (language seen as a set of items to be memorized) and qualitative (language seen as a means to communicate) comments. The authors found a strong relation between the language learners' pronunciation and qualitative language awareness. In a reanalysis of the Kennedy and Trofimovich data, Kennedy (2012) examined the language learners' L2 use across different contexts. No relation was observed between prosodic awareness and the amount of L2 use.

The same journal writing design was adopted in Kennedy and Blanchet (2014) and Kennedy et al. (2014) with French as a second language learners. In these studies, language learners' ability to perceive 
and produce connected L2 speech was found to be related to qualitative awareness about L2 prosody. However, quantitative awareness about L2 prosody was not related to speech perception and production. These studies suggest that not only the amount of knowledge the L2 learners possess about the L2 prosody matters, but also the way they view language in general.

Ramírez Verdugo (2006) examined L1 Spanish EFL learners' awareness about English intonation during a 10-week computer-assisted instruction program. Prosodic awareness was measured through a computer-assisted tool and a questionnaire. Learners recorded texts in English and compared them to native speaker recordings. Comparisons were aural as well as visual as participants were shown the pitch displays of the recordings. The participants gained accuracy and comprehensibility in their prosodic performance, and also reported to be more aware of English intonation after the training period.

The findings from previous studies on L2 prosodic awareness suggest that prosodic awareness is positively related to an individual's ability to produce (KENNEDYet al., 2014; KENNEDY; TROFIMOVICH, 2010) and perceive (KENNEDY; BLANCHET, 2014) the L2 accurately. Learners with higher prosodic awareness also improved their pronunciation faster than learners with lower awareness (KENNEDY; BLANCHET, 2014). However, it should be noted that the conceptualization of prosodic awareness in these studies has been different than in the L1 prosodic awareness research. Whereas L1 prosodic awareness research has focused on implicit testing methods, studies about L2 prosodic awareness have relied on participants' verbalization of the acquired knowledge. Furthermore, all of the L2 studies discussed above employed a training period during which the participants were exposed to explicit phonetics teaching and to activities designed to raise learners' consciousness about L2 prosody. Consequently, research on L2 prosodic awareness would benefit from employing implicit testing methods and from examining phonetically naïve individuals.

\subsection{Tonicity in General American English}

Tonicity, or the assignment of nuclear stress, has the function of highlighting the lexical item in the utterance the speaker considers the most important and wishes the interlocutor to focus on. This word is 
assigned with an extra prominence by means of a nuclear stress, which is an extra-heavy stress indicating a change in the pitch movement (WELLS, 2006). By default, nuclear stress is placed on the last stressed syllable of the intonation phrase. Nuclear stress assignment is nevertheless languagespecific and related to the information status of the constituents within the intonation phrase: information considered to be new is highlighted whereas given information is not. Consequently, L2 learners are required to become aware of the differences in nuclear stress assignment between their L1 and their L2 in order to produce target-like speech and avoid misunderstandings.

Nuclear stress assignment in broad focus context in General American English is governed by two principles: Germanic Nuclear Stress Rule and Anaphoric Deaccenting Rule (ZUBIZARRETA, 1998). We will shortly cover these rules and provide some examples to illustrate their functioning.

Although by default, the nuclear stress is located on the rightmost constituent of the intonation phrase, the Germanic Nuclear Stress Rule allows nuclear movement, as it is sensitive to predicate-argument relations and to the order of the sentence constituents (e.g. NAVA; ZUBIZARRETA, 2008). Consider the following examples (nuclear stress is indicated by underlining):

1. Lisa likes chocolate. (SVO)

2. Lisa's cat disappeared. (SV)

3. Lisa's crying/ Lisa's crying. (SV)

The nuclear stress falls on the rightmost constituent, as expected, in utterances ending in constituent other than a verb (Example 1). In intransitive constructions (Examples 2,3), the nuclear stress is variable and depends on the predicate structure and on the speaker's perception of the events reported. If the speaker views the information as thetic, i.e., simply states the event without providing a comment on it, the nuclear stress falls on the subject. If the speaker, on the other hand, perceives the event as categorical, i.e., states the event and provides a comment on it, the nuclear stress will fall on the verb. Previous research (NAVA; ZUBIZARRETA, 2010; ZUBIZARRETA; NAVA, 2011) indicates that native English speakers view unaccusative constructions as thetic (Example 2). Whereas unergative constructions can be viewed as thetic or categorical (Example 3 ), depending on the noteworthiness of the event described, unexpected events tend to be seen as categorical. 
It is worth highlighting that the above discussion applies to a broad focus context in which the speaker assumes all the information to be new for the interlocutor. In a narrow focus interpretation, nuclear stress can appear on other constituents to signal contrast or emphasis (focus domain indicated by square brackets):

4. [Lisa's arm hurts.]

5. Lisa's arm [hurts].

Whereas Example 4 presents a declarative statement in 'out of the blue' context, Example 5 establishes an implicit contrast: Lisa's arm HURTS, it is not BROKEN, for example.

Having discussed the Germanic Nuclear Stress Rule and how it affects on nuclear stress assignment, we will briefly discuss the Anaphoric Deaccenting Rule. This rule states that function words and previously mentioned information are deaccented in English, which greatly affects nuclear stress assignment in these contexts.

On the one hand, function words (pronouns, prepositions, copulas and auxiliary verbs) are deaccented in English so that they are normally unstressed and show vowel reduction. For this reason, function words cannot receive a nuclear stress in English in a broad focus context, so that if an utterance ends in a function word, the nuclear stress moves to a non-final position:

6. Tom called me.

7. Who are you talking to?

On the other hand, given information is deaccented in English whereas new information is accented, as this is the information the speaker wishes to bring into the listener's attention. Therefore, if an utterance ends in given information, the nuclear stress cannot appear on the final position in a broad focus context, but shifts to the left so that the given information will not receive unnecessary prominence:

8. Do you like the Guardian?

- I never read newspapers.

9. Could you prepare the dinner?

- I hate cooking. 
In Example 8, the speaker and the interlocutor share common knowledge about the fact that the Guardian is a newspaper, which is why the interlocutor does not need to bring that into focus and instead highlights the new information (she never reads newspapers). Example 9 shows how synonyms are also considered as given information. Because of this, the interlocutor removes importance from cooking and instead highlights his attitude toward it, which is unknown to the speaker.

The flexibility in English nuclear stress assignment needs to be acquired by language learners if they wish to communicate effectively. Nevertheless, it should be stated that nuclear stress assignment is not always a clear-cut matter because it is speaker- and context dependent. The focus domain, and thus nuclear stress assignment, is decided by the speaker based on the information he considers noteworthy to the interlocutor. This might or might not coincide with what the interlocutor considers noteworthy. Furthermore, the concept of given and new information can only be examined within a given context. Depending on the context, the same utterance can have several interpretations. Thus, nuclear stress assignment is never context neutral (ZUBIZARRETA; VERGNAUD, 2005).

\subsection{Tonicity in Brazilian Portuguese}

Brazilian Portuguese nuclear stress assignment is governed by the Romance Nuclear Stress Rule, which is more rigid than the earlier discussed Germanic Nuclear Stress Rule. In a broad focus context, nuclear stress is assigned to the rightmost constituent of the intonation phrase (MORAES, 1998; TENANI, 2002). Bringing constituents into focus, which in English is obtained through flexible nuclear stress assignment, is obtained through syntactic devices (word order, cleft- and pseudo-cleft constructions) in Spanish, European Portuguese, and other Romance languages. Consequently, nuclear stress movement to a non-final position calls for a contrastive interpretation in these languages.

Nevertheless, Brazilian Portuguese differs from the abovediscussed Romance languages in that its word order is more rigid. Brazilian Portuguese only has two unmarked word orders (SVO and SV) in comparison to European Portuguese, which allows for six different word orders (FERNANDES, 2007). From this, it follows that Brazilian Portuguese cannot resort to changes in word order to bring constituents into focus in the same manner as Spanish, for example. Previous research 
indicates that whereas English speakers resort mainly to prosodic devices to focalize constituents and Spanish and European Portuguese speakers resort mainly to syntactic devices, Brazilian Portuguese speakers appear to employ both strategies. Consider the following examples as an answer to the question 'What do you want?':

10. Eu quero [o livro]. ('I want the book.')

11. [O livro] |, eu quero. ('The book is what I want.')

12. O que eu quero é [o livro]. ('What I want is the book.')

Example 10 presents the unmarked SVO construction in which the nuclear stress falls on the last lexical item as determined by the Romance Nuclear Stress Rule. Example 11 shows the combination of syntactic and prosodic devices to bring the object into focus: the word order is changed by fronting the object and by placing it into a separate intonation phrase through topicalization. As the nuclear stress is required to appear on the last lexical item of the intonation phrase, the speaker's solution is to chunk up the utterance into two intonation phrases so that both, the object and the verb, receive a nuclear stress. Example 12 illustrates how focalization can be obtained by employing a cleft structure.

Apart from the syntactic devices of topicalization and cleft structures, Brazilian Portuguese can resort to at least two prosodic devices in order to bring constituents into focus. The first of these is chunking, as was seen in Example 11 above. This re-arranging of the speech material into new intonation phrases allows the nuclear stress to appear in the final position without resorting to awkward changes in the word order.

The other prosodic strategy, which differentiates Brazilian Portuguese from European Portuguese and other Romance languages as well as English, is the disassociation of the nuclear stress and the focal stress (MORAES, 2007). In English, the nuclear stress always appears on the focalized constituent as was seen in the previous section. In Brazilian Portuguese, two prosodic prominences can appear in an utterance: a fixed nuclear stress on the final constituent and a focal stress on the focalized constituent if the focalized constituent is not the last one in the intonation phrase (MORAES, 2007). Acoustically, when the focal stress is present, it is the most prominent stress in the intonational phrase (FERNANDES SVARTMAN, 2008). 
The placement of focal stress has been well established on topicalized subjects (FERNANDES, 2007; TRUCKENBRODT; SANDALO; ABAURRE, 2008). However, little research has been carried out about focalizing other sentence constituents, and research on focal stress placement in Brazilian Portuguese is highly required. It has been suggested that the speakers may place a phonetic boundary after the focalized constituent, so that the intonation unit is divided into two and the focused constituent aligns naturally with the intonation boundary where it would receive the nuclear stress (FROTA et al., 2015).

Some preliminary research also suggests that Brazilian Portuguese might allow deaccenting of given information similarly to English (footnote 15 in ZUBIZARRETA; NAVA, 2011). In a small-scale study, Kivistö-de Souza (2015) examined the contexts in which Brazilian Portuguese speakers $(n=10)$ employed focal stress. The results revealed that Brazilian Portuguese speakers placed a focal stress in $26 \%$ of the cases in utterances presenting given information and in $7.5 \%$ of the cases in utterances ending in function words. What is interesting about the findings is that in all the cases in which the focal stress was employed by the Brazilian Portuguese speakers, it was placed on the constituent which in English would receive the nuclear stress (e.g. 'Você conhece algum mexicano?' - 'Eu sou casada com um mexicano' / I'm married to a Mexican).

This preliminary research should be interpreted with caution due to the small sample size. That being said, should Brazilian Portuguese speakers employ a focal stress to deaccent given information in the same manner as English employs a nuclear stress, this could have a positive effect on their acquisition of the Anaphoric Deaccenting Rule. The L1 focal stress assignment strategy could be transferred into English in utterances presenting given information, resulting in target-like prosodic behavior in this context. As utterances ending in function words presented a low rate of focal stress assignment, it is likely that the deaccenting of function words in English would still be challenging for L1 Brazilian Portuguese speakers.

In order to acquire target-like English nuclear stress assignment, L1 Brazilian Portuguese speakers are required to develop awareness about the differences between the Germanic Nuclear Stress Rule and the Romance Nuclear Stress Rule, as well as to learn the contexts in which English allows for deaccenting (function words and previously mentioned information). Previous research with L1 Spanish learners of English indicates that the acquisition of the Anaphoric Deaccenting Rule is easier 
than the re-structuring of the Romance Nuclear Stress Rule (NAVA; ZUBIZARRETA, 2008, 2010). No previous studies have been carried out with L1 Brazilian Portuguese speakers, to the best of my knowledge, but it could be expected that the L1 Brazilian Portuguese speakers would behave similarly to the L1 Spanish speakers. The acquisition of targetlike nuclear stress assignment is desirable as the employment of incorrect prominence patterns is likely to lead into misunderstandings, both in perception and production.

\section{Research questions}

With the aim of examining L1 Brazilian Portuguese EFL learners' awareness about English prosody, the following research questions (RQs) and hypotheses (Hs) were formulated:

RQ 1. Are L1 Brazilian Portuguese speakers aware of English nuclear stress assignment? If so, is this awareness affected by sentence structure (unaccusative/deaccented)?

H 1: L1 Brazilian Portuguese EFL learners will manifest lower prosodic awareness than native English speakers due to their developing L2 phonology. As previous research suggests that the acquisition of Anaphoric Deaccenting Rule is easier than the restructuring of the Romance Nuclear Stress Rule (NAVA; ZUBIZARRETA, 2008, 2010), the L1 Brazilian Portuguese speakers are expected to show higher awareness about nuclear stress assignment in trials presenting deaccented information than in trials presenting unaccusative verbs.

RQ 2: Is L1 Brazilian Portuguese EFL learners' awareness about L2 nuclear stress assignment in utterances presenting deaccented information affected by the utterance type (functional category/given information)?

H 2: Awareness about L2 nuclear stress assignment in deaccented sentences is expected to be higher in trials ending in given information than in trials ending in function words. This is because previous research has suggested that in utterances with given information, Brazilian Portuguese speakers may employ a focal stress, whose placement coincides with the L2 nuclear stress (KIVISTÖ-DE SOUZA, 2015). Consequently, this strategy could be positively transferred into the L2, resulting in higher awareness. 


\section{Method}

The present study tested L1 Brazilian Portuguese learners of English about their sensitivity to English nuclear stress assignment with a psycholinguistic perception task. The task consisted of low-pass filtered mini-dialogues which presented adequate and inadequate English intonation patterns. Participants' accuracy in being able to reject the inadequate intonation patterns was taken to reflect their awareness about L2 nuclear stress assignment.

\subsection{Participants}

Two groups of participants were tested: native speakers of Brazilian Portuguese and native speakers of American English. The L1 Brazilian Portuguese speakers were 69 English learners from the Federal University of Santa Catarina (UFSC) with a mean age of $25.78(S D=7.60)$. According to their English vocabulary size $(M=4157, S D=576$, max. $=$ 5,000 ), which was measured with $X \_$lex vocabulary size test (MEARA, 2005), the L1 Brazilian Portuguese participants were classified as having an advanced proficiency level (CEFR C1: MILTON, 2010). Sixty-six percent of the L1 Brazilian Portuguese participants were female and 33\% were male. All the EFL learners had grown in a monolingual Brazilian Portuguese household and had been exposed to English for the first time at school (AOL $M=9.28, S D=2.78) .{ }^{2}$ Overall, their experience with English was limited. On average, the L1 Brazilian Portuguese EFL learners had been employing English 21\% of the time in the five years preceding the data collection $(S D=14.49)$. Their mean length of stay in English-speaking countries was 4.3 months $(S D=11.42)$, and only 13 percent had frequent contact with native English speakers. What is more, 88 percent had never attended a course in English phonetics and phonology.

The L1 American English speakers $(n=16)$ functioned as a baseline data against which the EFL learners' task behavior could be compared. They were recruited among the exchange students attending university-

\footnotetext{
${ }^{2}$ The vast majority ( $80 \%$ ) of the L1 Brazilian Portuguese speakers had been born in the South of Brazil, $15 \%$ in Southeast, two participants in the Central-West and one participant in the Northeast.
} 
level classes in Florianópolis. ${ }^{3}$ Ten of the L1 American English speakers were female and six were male. Their mean age was $24.19(S D=7.11)$ and they all had become exposed to Brazilian Portuguese as adults (AOL $M=22.88, S D=5.67)$. The native English speakers' experience with Brazilian Portuguese was predominantly limited: 88 percent had stayed in Brazil for less than six months. On average, they had studied Portuguese for 1.3 years $(S D=2.49)$. Moreover, only $12 \%$ considered themselves fluent in Portuguese. None of the L1 Brazilian Portuguese or L1 American English participants had been diagnosed with a hearing problem.

\subsection{Stimuli}

Stimuli created for the task consisted of question-answer pairs in which the answer (the target) was low-pass filtered. Two types of trials were created, those which presented appropriate General American intonation patterns but which were incorrect if transposed into Brazilian Portuguese ('yes' trials), and those which presented inappropriate General American intonation patterns, but which were correct if transposed into Brazilian Portuguese ('no' trials). Additionally, two sentence structures were tested: unaccusative and deaccented. Within the deaccented category, half of the items ended in function words ('functional') and half in given information ('given') (Table 1). All of the trials but four of the deaccented 'given' had a broad information focus.

TABLE 1

Overview of the trial types

\begin{tabular}{cccc}
\hline & & \multicolumn{2}{c}{ Intonation pattern } \\
\cline { 3 - 3 } $\mathrm{N}^{\circ}$ of trials $(n=58)$ & Type & \multicolumn{2}{c}{ Appropropriate in BP } \\
\cline { 3 - 3 } 14 & Unaccusative & $\sqrt{ }$ & $\chi$ \\
12 & Unaccusative & $\chi$ & $\sqrt{ }$ \\
16 & Deaccented & $\sqrt{ }$ & $\chi$ \\
16 & Deaccented & $\chi$ & $\sqrt{ }$ \\
\hline
\end{tabular}

${ }^{3}$ Three of the L1 AmE participants were permanently residing in Florianópolis (mean $\mathrm{LOR}=4.08 \mathrm{y}, S D=5.19)$. Their task performance did not differ from the L1 AmE participants residing in the US, which is why their data was included in the analyses. 
The answer targets were created by taking into account memory constraints and vocabulary familiarity. The yes-no trials design was created by having parallel sentences, half of which followed the English tonicity rules and half of which broke them but followed the Brazilian Portuguese tonicity rules:

13. What's the matter?

- I want to see you. ('yes' trial)

14 What's the matter?

- I can't hear you. ('no' trial)

The questions in the mini-dialogues provided the context against which the listener would judge the correctness of the tonicity pattern in the answer. For this reason, it was crucial that the question prompts would elicit an answer with only one possible tonicity pattern. All the questions were unmarked (genuine questions). The following example illustrates a question prompt with its appropriate answer and two alternative tonicity patterns which would not be possible answers in this context:

\section{Why is she sad?}

- Their friendship ended.

_*Their friendship ended. ('What happened to their friendship?')

-*Their friendship ended. ('Whose friendship ended?')

The stimuli was recorded by two female native speakers of American English. First, a list of question prompts was created with three randomized repetitions of each question. A 35-year old female from California with no knowledge of Portuguese was recorded at the phonetics laboratory of the University of Barcelona in a sound-proof booth. The informant was instructed to read the question prompts in a natural and clear manner, as if asking a real question. The most natural repetition of each question prompt was selected.

A 44-year old female, also born and raised in California, recorded the answer prompts at UFSC in a soundproof booth. In order to ensure that the informant produced the expected intonation patterns, she provided the answers while listening to the previously recorded question prompts. 
A concatenated sound file was created which presented two repetitions of the question prompts. The questions were randomly inserted in the sound file and separated by 4-second pauses. Prior to recording, the informant read a list with the question-answer pairs and was instructed to listen to the question and read the answer as if genuinely answering to the question during the pause. The informant was also instructed to employ falling intonation, as is common for statements, and to avoid very expressive answers.

In order to elicit the answers to the 'no' trials, those presenting inadequate English intonation patterns, the researcher recorded a set of question prompts which elicited a contrastive narrow focus. The questions were inserted into a concatenated sound file, following the procedure described above, and elicited from the second native female speaker in the same manner as the answers to the 'yes', correct, trials. See the following example dialogues for 'yes' and 'no' trials:

16. And then what happened? (unmarked question)

- The film started. ('yes' trial)

17. Did the game finish? (marked question)

- No. The game started. ('no' trial)

A selection was made with the several repetitions of each target answer. The most natural sounding answers with the clearest pronunciation which matched the speed of the earlier recorded question prompts were selected. The answers were extracted at zero crossing and preprocessed for presentation together with the question prompts. In case of the answers to the 'no' trials, in which the target was preceded by negation (see example above), the negation was always followed by a prosodic pause and the negation was thus easily removed before the extraction of the target. The answers were low-pass filtered at $450 \mathrm{~Hz}$ and smoothed at $20 \mathrm{~Hz}$. As a result, most of the segmental information was removed from the signal whereas the suprasegmental information was maintained. Next, the questions and the answers were cleaned from low-frequency noise and their amplitude was adjusted to the same level. As a result, the final stimuli consisted of 58 question-answer pairs in which the question presented normal sound quality and the answer was low-pass filtered so that the answers sounded muffled as if heard through a wall. The stimuli can be seen in the following Table 2 . 
TABLE 2

Stimuli for the Low-pass filtered intonation identification task

TEST TRIALS $(N=\mathbf{5 8})$

\begin{tabular}{|c|c|c|c|c|c|c|c|}
\hline \multicolumn{8}{|c|}{ UNACCUSATIVE $(n=26)$} \\
\hline \multicolumn{4}{|c|}{ 'yes' trials $(n=14)$} & \multicolumn{4}{|c|}{ 'no' trials $(n=12)$} \\
\hline $\begin{array}{c}\text { Trial } \\
\mathrm{n}^{\circ}\end{array}$ & $\begin{array}{l}\text { CONTEXT: } \\
\text { Question }\end{array}$ & $\begin{array}{l}\text { TARGET: } \\
\text { Answer }\end{array}$ & FD & $\begin{array}{c}\text { Trial } \\
\mathrm{n}^{\circ}\end{array}$ & $\begin{array}{l}\text { CONTEXT: } \\
\text { Question }\end{array}$ & $\begin{array}{l}\text { TARGET: } \\
\text { Answer }\end{array}$ & FD \\
\hline 001 & $\begin{array}{l}\text { And then what } \\
\text { happened? }\end{array}$ & $\begin{array}{c}\text { New } \\
\text { evidence } \\
\text { emerged. }\end{array}$ & B & 101 & $\begin{array}{l}\text { What happened } \\
\text { before the party? }\end{array}$ & $\begin{array}{l}\text { Many guests } \\
\text { arrived. }\end{array}$ & B \\
\hline 002 & $\begin{array}{l}\text { What } \\
\text { happened? }\end{array}$ & $\begin{array}{l}\text { The flight } \\
\text { departed. }\end{array}$ & B & 103 & $\begin{array}{l}\text { What happened } \\
\text { next? }\end{array}$ & The train departed. & B \\
\hline 003 & $\begin{array}{l}\text { Why are the } \\
\text { kids upset? }\end{array}$ & $\begin{array}{c}\text { Their cat } \\
\text { disappeared. }\end{array}$ & B & 104 & Why are you sad? & $\begin{array}{c}\text { My wallet } \\
\text { disappeared. }\end{array}$ & B \\
\hline 008 & $\begin{array}{l}\text { Why are the } \\
\text { kids upset? }\end{array}$ & $\begin{array}{l}\text { Their } \\
\text { chocolate } \\
\text { melted. }\end{array}$ & B & 108 & $\begin{array}{l}\text { Why is the road } \\
\text { wet? }\end{array}$ & The snow melted. & B \\
\hline 010 & $\begin{array}{c}\text { What was that } \\
\text { noise? }\end{array}$ & $\begin{array}{l}\text { A window } \\
\text { broke. }\end{array}$ & B & 110 & $\begin{array}{c}\text { What was that } \\
\text { noise? }\end{array}$ & A glass broke. & B \\
\hline 015 & $\begin{array}{c}\text { Why are you } \\
\text { happy? }\end{array}$ & $\begin{array}{l}\text { My salary } \\
\text { increased. }\end{array}$ & B & 115 & $\begin{array}{c}\text { Why is your boss } \\
\text { upset? }\end{array}$ & $\begin{array}{l}\text { The taxes } \\
\text { increased. }\end{array}$ & B \\
\hline 016 & $\begin{array}{l}\text { What } \\
\text { happened in } \\
\text { the meeting? }\end{array}$ & $\begin{array}{c}\begin{array}{c}\text { Some } \\
\text { problems }\end{array} \\
\text { arose. }\end{array}$ & B & 116 & $\begin{array}{c}\text { What happened } \\
\text { last week? }\end{array}$ & $\begin{array}{l}\text { The temperature } \\
\text { rose. }\end{array}$ & B \\
\hline 018 & $\begin{array}{l}\text { What had } \\
\text { caused the } \\
\text { accident? }\end{array}$ & $\begin{array}{l}\text { The brakes } \\
\text { had failed. }\end{array}$ & B & 118 & $\begin{array}{l}\text { What caused the } \\
\text { accident? }\end{array}$ & The motor failed. & B \\
\hline 012 & $\begin{array}{l}\text { What happened } \\
\text { next? }\end{array}$ & $\begin{array}{l}\text { The ceiling } \\
\text { collapsed. }\end{array}$ & B & 119 & $\begin{array}{c}\text { What's the matter } \\
\text { with her? }\end{array}$ & Her arm hurts. & B \\
\hline 014 & $\begin{array}{l}\text { What's that } \\
\text { smell? }\end{array}$ & $\begin{array}{l}\text { The cake } \\
\text { burned. }\end{array}$ & B & 121 & $\begin{array}{c}\text { What happened at } \\
\text { the court? }\end{array}$ & $\begin{array}{l}\text { The lawyers } \\
\text { settled. }\end{array}$ & B \\
\hline 021 & $\begin{array}{c}\text { And then what } \\
\text { happened? }\end{array}$ & The film & B & 123 & $\begin{array}{l}\text { And then what } \\
\text { happened? }\end{array}$ & The game started. & B \\
\hline 024 & $\begin{array}{l}\text { Why is she } \\
\text { sad? }\end{array}$ & $\begin{array}{l}\text { Their } \\
\text { friendship } \\
\text { ended. }\end{array}$ & B & 125 & $\begin{array}{l}\text { Why is she } \\
\text { crying? }\end{array}$ & $\begin{array}{l}\text { Their relationship } \\
\text { ended. }\end{array}$ & B \\
\hline 009 & $\begin{array}{c}\text { What } \\
\text { happened } \\
\text { next? }\end{array}$ & $\begin{array}{c}\text { The lake } \\
\text { froze. }\end{array}$ & B & & & & \\
\hline 011 & $\begin{array}{c}\text { What's going } \\
\text { on? }\end{array}$ & $\begin{array}{l}\text { The ship's } \\
\text { sinking. }\end{array}$ & B & & & & \\
\hline
\end{tabular}




\section{DEACCENTED $(n=32)$}

'yes' trials $(n=19)$

'no' trials $(n=19)$

Deaccented: Functional category $(n=16)$

'yes' trials $(n=8)$

'no' trials $(n=8)$

\begin{tabular}{|c|c|c|c|c|c|c|c|}
\hline $\begin{array}{c}\text { Trial } \\
\mathrm{n}^{\mathrm{o}}\end{array}$ & $\begin{array}{l}\text { CONTEXT: } \\
\text { Question }\end{array}$ & $\begin{array}{l}\text { TARGET: } \\
\text { Answer }\end{array}$ & FD & $\begin{array}{c}\text { Trial } \\
\mathrm{n}^{\mathrm{o}}\end{array}$ & $\begin{array}{l}\text { CONTEXT: } \\
\text { Question }\end{array}$ & $\begin{array}{l}\text { TARGET: } \\
\text { Answer }\end{array}$ & FD \\
\hline 026 & $\begin{array}{l}\text { What's the } \\
\text { matter? }\end{array}$ & $\begin{array}{c}\text { I want to see } \\
\text { you. }\end{array}$ & $\mathrm{B}$ & 126 & $\begin{array}{l}\text { What's the } \\
\text { matter? }\end{array}$ & I can't hear you. & $\mathrm{B}$ \\
\hline 027 & $\begin{array}{l}\text { Why didn't } \\
\text { you answer his } \\
\text { calls? }\end{array}$ & $\begin{array}{l}\text { I'm very } \\
\text { annoyed } \\
\text { with him. }\end{array}$ & B & 127 & $\begin{array}{l}\text { Why didn’t Tina } \\
\text { answer his calls? }\end{array}$ & $\begin{array}{c}\text { She's very irritated } \\
\text { with } \underline{\text { him. }}\end{array}$ & $\mathrm{B}$ \\
\hline 028 & $\begin{array}{l}\text { And then what } \\
\text { happened? }\end{array}$ & $\begin{array}{l}\text { I received } \\
\text { an email } \\
\text { from her. }\end{array}$ & $\mathrm{B}$ & 128 & $\begin{array}{l}\text { And then what } \\
\text { happened? }\end{array}$ & $\begin{array}{l}\text { Mark got a gift } \\
\text { from her. }\end{array}$ & $\mathrm{B}$ \\
\hline 029 & $\begin{array}{l}\text { What should } \\
\text { I do? }\end{array}$ & $\begin{array}{l}\text { You should } \\
\text { talk to your } \\
\text { boss about } \\
\text { it. }\end{array}$ & $\mathrm{N}$ & 132 & $\begin{array}{l}\text { Did you hear what } \\
\text { happened at the } \\
\text { interview? }\end{array}$ & $\begin{array}{l}\text { I didn't ask her } \\
\text { about it. }\end{array}$ & B \\
\hline 030 & $\begin{array}{l}\text { What's the } \\
\text { matter with } \\
\text { your dress? }\end{array}$ & $\begin{array}{l}\text { There's a } \\
\text { stain on it. }\end{array}$ & B & 130 & $\begin{array}{l}\text { What's the matter } \\
\text { with your shirt? }\end{array}$ & There's a hole in it. & B \\
\hline 032 & What's that? & $\begin{array}{l}\text { It's a } \\
\text { delivery for } \\
\text { you. }\end{array}$ & $\mathrm{N}$ & 133 & $\begin{array}{c}\text { Did you hear what } \\
\text { happened at the } \\
\text { party? }\end{array}$ & No one told me. & B \\
\hline 033 & $\begin{array}{l}\text { Have you seen } \\
\text { today's paper? }\end{array}$ & $\begin{array}{l}\text { No, give it } \\
\text { to me. }\end{array}$ & B & 139 & $\begin{array}{c}\text { Have you seen my } \\
\text { keys? }\end{array}$ & $\begin{array}{l}\text { I haven't seen } \\
\text { them. }\end{array}$ & $\mathrm{N}$ \\
\hline 041 & $\begin{array}{c}\text { Do you have a } \\
\text { computer? }\end{array}$ & $\begin{array}{l}\text { I have to } \\
\text { buy one. }\end{array}$ & B & 134 & $\begin{array}{c}\text { Where's the } \\
\text { hotel? }\end{array}$ & $\begin{array}{l}\text { We should ask } \\
\text { someone. }\end{array}$ & $\mathrm{B}$ \\
\hline
\end{tabular}




\section{Deaccented: Given information $(n=16)$}

\begin{tabular}{|c|c|c|c|c|c|c|c|}
\hline \multicolumn{4}{|c|}{ 'yes' trials $(n=8)$} & \multicolumn{4}{|c|}{ 'no' trials $(n=8)$} \\
\hline $\begin{array}{c}\text { Trial } \\
\mathrm{n}^{\circ}\end{array}$ & $\begin{array}{l}\text { CONTEXT: } \\
\text { Question }\end{array}$ & $\begin{array}{l}\text { TARGET: } \\
\text { Answer }\end{array}$ & FD & $\begin{array}{c}\text { Trial } \\
\mathrm{n}^{\circ}\end{array}$ & $\begin{array}{l}\text { CONTEXT: } \\
\text { Question }\end{array}$ & $\begin{array}{c}\text { TARGET: } \\
\text { Answer }\end{array}$ & $\mathrm{FD}$ \\
\hline 042 & $\begin{array}{l}\text { What's that } \\
\text { noise? }\end{array}$ & $\begin{array}{l}\text { The dog's } \\
\text { barking. }\end{array}$ & B & 120 & What's that noise? & $\begin{array}{l}\text { The doorbell's } \\
\text { ringing. }\end{array}$ & B \\
\hline 056 & $\begin{array}{l}\text { What } \\
\text { happened } \\
\text { before the } \\
\text { party? }\end{array}$ & $\begin{array}{l}\text { The } \\
\text { telephone } \\
\text { rang. }\end{array}$ & B & 141 & What's that noise? & $\begin{array}{l}\text { The telephone's } \\
\text { ringing. }\end{array}$ & B \\
\hline 044 & $\begin{array}{l}\text { Will you travel } \\
\text { by plane? }\end{array}$ & $\begin{array}{l}\text { I'm } \underline{\text { scared }} \\
\text { of flying. }\end{array}$ & $\mathrm{B}$ & 143 & $\begin{array}{l}\text { Will you go by } \\
\text { foot? }\end{array}$ & $\begin{array}{l}\text { I'm tired of } \\
\text { walking. }\end{array}$ & B \\
\hline 045 & $\begin{array}{l}\text { Could you do } \\
\text { the laundry? }\end{array}$ & $\begin{array}{l}\text { I hate } \\
\text { washing } \\
\text { clothes. }\end{array}$ & $\mathrm{B}$ & 144 & $\begin{array}{c}\text { Could you prepare } \\
\text { dinner? }\end{array}$ & I hate cooking. & B \\
\hline 049 & What's that? & $\begin{array}{l}\text { That's the } \\
\text { film Laura } \\
\text { rented. }\end{array}$ & $\mathrm{N}$ & 148 & What's that? & $\begin{array}{l}\text { That's the book } \\
\text { John wrote. }\end{array}$ & $\mathrm{N}$ \\
\hline 050 & $\begin{array}{l}\text { What's that on } \\
\text { the stove? }\end{array}$ & $\begin{array}{l}\text { That's the } \\
\text { dinner I was } \\
\text { making. }\end{array}$ & $\mathrm{N}$ & 149 & $\begin{array}{c}\text { What's that on the } \\
\text { plate? }\end{array}$ & $\begin{array}{l}\text { That's the salad I } \\
\text { was eating. }\end{array}$ & $\mathrm{N}$ \\
\hline 037 & $\begin{array}{c}\text { What are you } \\
\text { having for } \\
\text { dinner? }\end{array}$ & $\begin{array}{c}\text { We're } \\
\text { having } \\
\text { chicken for } \\
\text { dinner. }\end{array}$ & $\mathrm{N}$ & 135 & $\begin{array}{c}\text { What are you } \\
\text { having for lunch? }\end{array}$ & $\begin{array}{l}\text { I'm having a } \\
\text { sandwich for } \\
\text { lunch. }\end{array}$ & $\mathrm{N}$ \\
\hline 055 & $\begin{array}{c}\text { Do you } \\
\text { want some } \\
\text { chocolate? }\end{array}$ & $\begin{array}{l}\text { I also want } \\
\text { some other } \\
\text { sweets. }\end{array}$ & $\mathrm{N}$ & 155 & $\begin{array}{l}\text { Did you buy } \\
\text { carrots? }\end{array}$ & $\begin{array}{l}\text { I also bought some } \\
\text { other vegetables. }\end{array}$ & $\mathrm{N}$ \\
\hline
\end{tabular}

Note: Underlining indicates the nuclear stress position.

$\mathrm{FD}=$ Focus domain; $\mathrm{B}=$ Broad, $\mathrm{N}=$ Narrow

\subsection{Instrument and procedure}

Participants' awareness about English nuclear stress assignment was tested with a psycholinguistic perception test, Low-pass filtered intonation identification task. In this task, participants listened to question-answer dialogues and indicated by pressing the corresponding 
keyboard key whether the intonation in the answer was appropriate to the context provided by the question.

Low-pass filtering was applied to the answer targets in order to draw the participants' attention into intonation without intervening segmental information. Previous research indicates that low-pass filtering renders well for listening tasks in which prosodic information is on the focus. In L1 research with children, low-pass filtering has been successfully employed in tasks testing children's implicit prosodic awareness (e.g. WOOD; TERRELL, 1998). In adult L2 learners, low-pass filtering has been exploited, for example, in foreign accent judgments (TROFIMOVICH; BAKER, 2006), foreign accent recognition (JILKA, 2000) and intonation pattern perception (PASSARELLA DOS REIS, GONÇALVES; SILVEIRA, 2016). Overall, it seems that low-pass filtering encourages the listener to consciously pay attention to prosody, which in normal speech may be left unattended.

The task was created and administered with DmDx software (FORSTER; FORSTER, 2012), and consisted of practice trials with feedback $(n=5)$ and randomized test trials. A practice block was included in order to familiarize the participants with low-pass filtered speech. After the practice block, participants were encouraged to voice any questions about the task. Each test trial unfolded as follows (see illustration in Figure 1). First, an image of a loudspeaker appeared on the screen to draw the participant's focus on the upcoming audio file. Next, the question prompt was heard in normal sound quality. Following the question, the answer was displayed orthographically on the screen, where it remained for $2500 \mathrm{~ms}^{4}$. The orthographic presentation of the answer was necessary as due to low-pass filtering, no individual words could be deciphered and the meaning of the utterance would have been lost. The orthographic presentation of the answer before its acoustic presentation was also expected to trigger the need to retrieve the prosodic representation of the utterance from the learner's long-term memory, as readers provide intonation to text when silently reading it. This long-term representation could then be compared to the low-pass filtered speech signal presented

\footnotetext{
${ }^{4}$ Previous piloting of the task suggested that this time limit was enough for the foreign language learners to read and comprehend the sentence. Simultaneously, the limit was short enough to allow the retention of the question-answer sequence in the short-term memory in order to perform the required comparison operation.
} 
immediately after, in order to decide whether a match was found or not. Next, an image of a loudspeaker appeared again in order to prepare the participant for the acoustic presentation of the answer. This was immediately followed by a low-pass filtered audio presentation of the orthographic answer. Finally, the participant was asked to judge whether the intonation in the answer was appropriate to the question. The entire task took around 15-20 minutes to complete.

Testing was carried out individually in a quiet room at UFSC. Participants took several phonological awareness tasks, out of which only the one corresponding to the prosodic domain is reported here. Before testing, all participants signed a consent form in which they agreed to participate in the study.

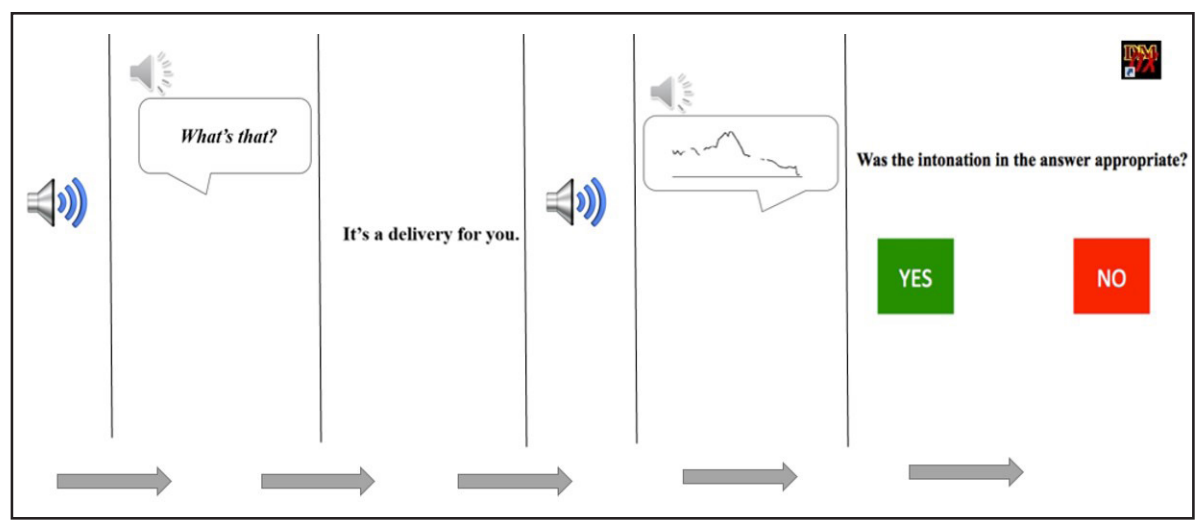

FIGURE 1- Illustration of the test trial structure. The gray loudspeakers stand for the presentation of the auditory stimulus.

Participants' awareness about English nuclear stress placement was examined by computing mean identification accuracy scores for individual trials, and then to trials grouped by sentence type (unaccusative/ deaccented; deaccented 'given'-deaccented 'functional') and intonation pattern legality (correct/incorrect). Participants' prosodic awareness was expected to be manifested especially in the response accuracy to the incorrect ('no') trials. This is because awareness manifested in the ability to accept correct intonation patterns is likely to be confounded with positive evidence from the L2 input. On the contrary, rejecting incorrect intonation patterns cannot be based on positive evidence from the input, and thus the ability to reject incorrect intonation patterns should manifest the underlying awareness about target language prosody more clearly. 


\section{Results}

As expected, the L1 Brazilian Portuguese EFL learners showed lower response accuracy across sentence types and intonation patterns than the native English speakers (Table 3). Differences as a function of intonation pattern (correct, 'yes'/ incorrect, 'no') can also be observed as the 'no' trials tended to present a lower response accuracy than the 'yes' trials.

TABLE 3

Mean response accuracy (\%) across sentence types and intonation patterns for L1 Brazilian Portuguese and L1 American English participants

\begin{tabular}{|c|c|c|c|c|c|}
\hline \multirow[b]{2}{*}{ Sentence type } & \multirow[b]{2}{*}{$\begin{array}{c}\text { Intonation } \\
\text { pattern }\end{array}$} & \multicolumn{2}{|c|}{ L1 BP $(n=69)$} & \multicolumn{2}{|c|}{ L1 AmE $(n=16)$} \\
\hline & & $M$ & $S D$ & M & SD \\
\hline \multirow{2}{*}{ Unaccusative } & 'yes' & 68.32 & 20.36 & 94.64 & 13.17 \\
\hline & 'no' & 39.73 & 20.06 & 70.31 & 21.72 \\
\hline \multirow{2}{*}{ Deaccented } & ‘yes’' & 84.78 & 11.00 & 91.40 & 10.91 \\
\hline & 'no' & 63.85 & 16.87 & 90.62 & 8.83 \\
\hline \multirow{2}{*}{$\begin{array}{l}\text { Deaccented } \\
\text { 'functional' }\end{array}$} & ‘yes’ & 90.03 & 11.85 & 90.62 & 10.70 \\
\hline & 'no' & 75.90 & 17.84 & 95.31 & 8.98 \\
\hline \multirow{2}{*}{$\begin{array}{l}\text { Deaccented } \\
\text { 'given' }\end{array}$} & ‘yes’ & 79.52 & 15.89 & 92.18 & 15.05 \\
\hline & 'no' & 51.81 & 21.78 & 85.93 & 17.60 \\
\hline
\end{tabular}

With the aim of examining L1 Brazilian Portuguese speakers' awareness about English nuclear stress assignment (RQ 1), the mean response accuracy percentages across sentence types and intonation patterns were compared to the native English speakers. A mixed ANOVA was conducted with two within-subjects variables, Sentence Type (Unaccusative/Deaccented) and Intonation Pattern (yes/no), and with one between-subjects variable, L1 (BP/AmE). The dependent measure was Response Accuracy. The ANOVA yielded significant main effects of Sentence Type, $F(1,83)=53.05, p<.001, \eta 2=.39$, Intonation Pattern, $F(1,83)=55.44, p<.001, \eta^{2}=.40$, and $L 1, F(1,83)=55.95, p<.001$, $\eta^{2}=.40$. The Sentence Type x $L 1$ interaction, $F(1,83)=8.82, p=.004$, $\eta^{2}=.09$, and the Intonation Pattern $\mathrm{x} L 1$ interaction, $F(1,83)=5.92, p$ $=.017, \eta^{2}=.06$, were also significant. 
In order to determine the cause of the interaction effects, posthoc t-test were ran separately for the two participant groups. The Sentence Type $x$ L1 interaction occurred because the L1 Brazilian Portuguese speakers' response accuracy was significantly higher for the deaccented 'yes' and 'no' trials than for the unaccusative 'yes' and 'no' trials ( $p$ $<.001$ ). On the contrary, the native English speakers' response accuracy was significantly higher for the deaccented 'no' trials than for the unaccusative 'no' trials $(p<.001)$, but not for the deaccented 'yes' trials and the unaccusative 'yes' trials $(p=.302)$. To put another way, whereas the L1 Brazilian Portuguese EFL learners showed a clear effect of Sentence Type, so that deaccented trials were found overall easier than the unaccusative trials, for the native English speakers, the effect of sentence type only became evident in the 'no' trials (Figure 2).

The Intonation Pattern $x$ L1 interaction was due to the fact that whereas the L1 Brazilian Portuguese participants' response accuracy in the 'yes' trials was consistently higher than in the 'no' trials $(p<.001)$, this did not happen with the native English speakers. The native English speakers did not show a significant difference between the response accuracy of the deaccented 'yes' and 'no' trials $(p=.835)$. In other words, whereas for the L1 Brazilian Portuguese speakers identifying the correct intonation patterns was easier than rejecting the incorrect intonation patterns, for the native English speakers this phenomenon was observed only in the unaccusative sentence type.

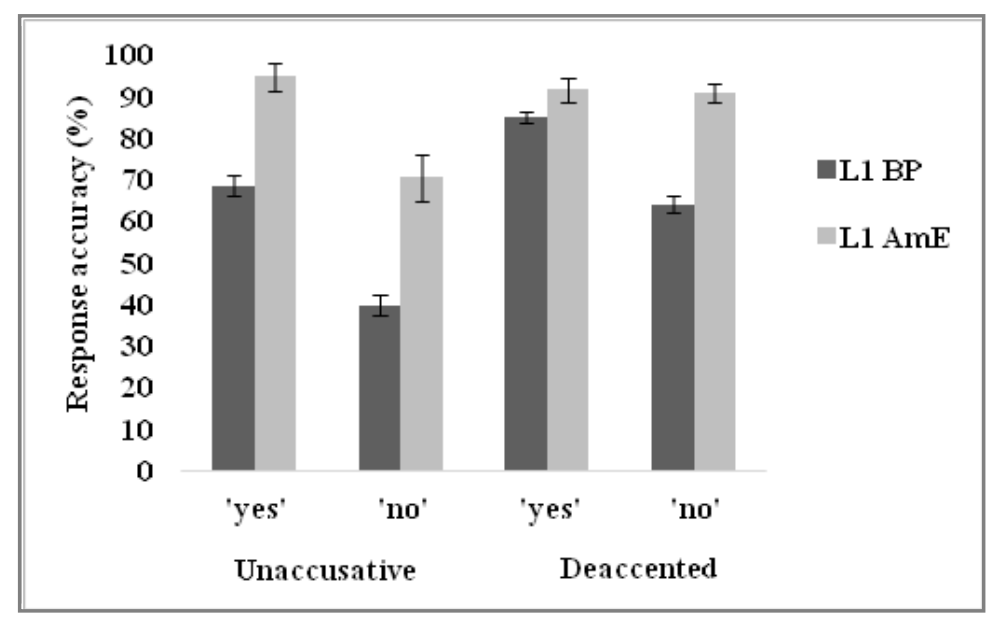

FIGURE 2- Mean response accuracy across sentence types and intonation patterns (error bars represent \pm 1 standard error) 
These results revealed three aspects about L1 Brazilian Portuguese EFL learners' awareness of English nuclear stress assignment. First, The L1 Brazilian Portuguese speakers manifested a significantly lower response accuracy in all test categories than the native English speakers (the differences were significant at $p<.001$ level for all the comparisons, except deaccented 'yes' trials, for which the difference was significant at $p=.033$ ). This confirmed the initial hypothesis that language learners' awareness is lower than native speakers' due to the differences in the completeness of the phonological representations. Second, as predicted, identifying correct intonation patterns ('yes' trials) was significantly easier for the L1 Brazilian Portuguese speakers than rejecting incorrect intonation patterns ('no'). This seems to confirm that whereas for the correct, 'yes' trials, awareness about L2 phonology can be confounded with positive evidence from the L2 input, rejecting the incorrect intonation patterns requires acquired awareness about the target structure. Finally, the deaccented trials were easier for the L1 Brazilian Portuguese participants than the unaccusative trials. For the native English speakers, a difference was only observed in the case of unaccusative 'no' trials, which presented a significantly lower response accuracy than all the other trial types. This result extends previous research with native Spanish speakers to Brazilian Portuguese speakers: the acquisition of the Anaphoric Deaccenting Rule does appear to be easier for speakers of Romance languages than the restructuring of the Romance Nuclear Stress Rule (NAVA; ZUBIZARRETA, 2008, 2010).

In order to further examine L1 Brazilian Portuguese EFL learners' awareness about English nuclear stress assignment, performance in the deaccented trials was scrutinized. The aim was to investigate whether differences could be observed between deaccented trials ending in given information ('given') and those ending in function words ('functional') (RQ 2). It was hypothesized that L1 Brazilian Portuguese speakers could transfer L1 focal stress assignment strategies into the L2, which would especially benefit the acquisition of English nuclear stress in utterances presenting given information as this is the context in which L1 focal stress assignment has been shown to be the highest.

Examination of the descriptive statistics indicated that response accuracy in the 'functional' trials was higher than in the 'given' trials, contrary to the predictions (Table 3). As the data was not normally distributed but mostly skewed to the right, Wilcoxon Signed Rank test were employed separately to the 'yes' and the 'no' trials to investigate 
whether the observed differences were statistically significant ${ }^{5}$. The answers to the 'yes' trials differed significantly $(Z=-4.50, p<.001)$, as did the answers to the 'no' trials $(Z=-6.32, p<.001)$, showing that the L1 Brazilian Portuguese participants had developed higher awareness about English nuclear stress assignment for utterances ending in function words than for utterances ending in given information (Figure 3). This finding did not support the initial hypothesis (H 2) according to which L1 Brazilian Portuguese speakers might find the trials ending in given information easier due to the positive transfer of L1 focal stress. Utterances ending in function words are not deaccented in Brazilian Portuguese, which seems to indicate that the L1 Brazilian Portuguese participants of the study had developed awareness about English nuclear stress assignment, especially in the context of functional categories. In the case of deaccented trials ending in given information, the response accuracy was nearly at chance level in the trials presenting incorrect intonation patterns (51.8\%), which demonstrates that the L1 Brazilian Portuguese EFL learners as a group had not developed awareness about L2 nuclear stress assignment in utterances ending in given information.

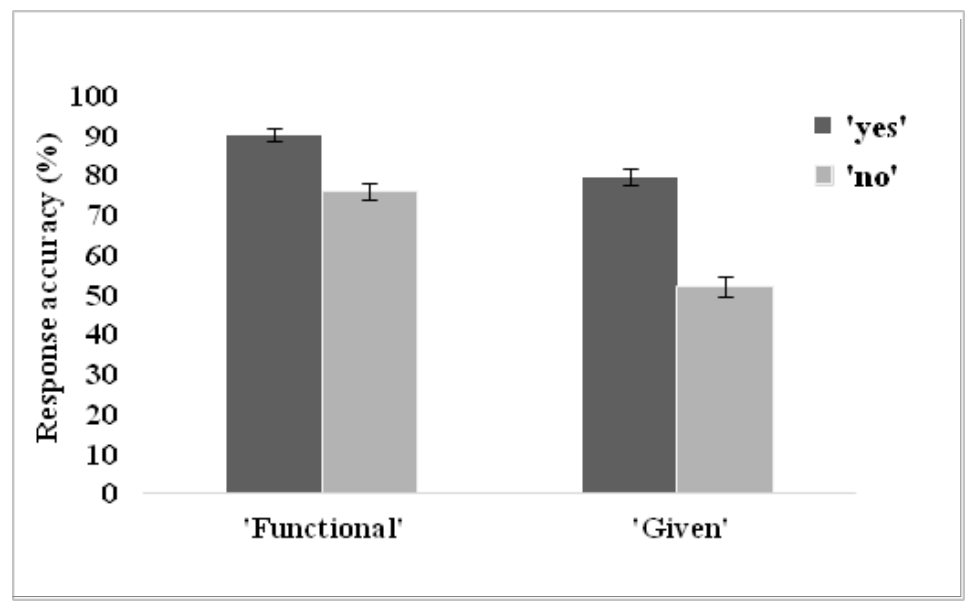

FIGURE 3- Mean response accuracy in Deaccented subtypes for L1 Brazilian Portuguese participants (error bars represent \pm 1 standard error)

\footnotetext{
${ }^{5}$ The "given" category included items with broad and narrow information focus. These were analyzed together as no differences were found in their identification accuracy: L1 BP broad_yes - narrow_yes $t(68)=-.1 .94, p=.056$, broad_no - narrow_no $t(68)=1.65, p>.05$.
} 


\section{Discussion and conclusions}

The present study examined L1 Brazilian Portuguese EFL learners' awareness about English nuclear stress assignment with a psycholinguistic perception task which tapped into non-verbalizable awareness about the L2 prosody. The findings showed that L1 Brazilian Portuguese learners of English had lower awareness about English nuclear stress assignment than native English speakers. Differences were also observed in terms of utterance type. L1 Brazilian Portuguese ELF learners' awareness about English nuclear stress assignment was higher in utterances presenting deaccented information than in unaccusative sentences. Furthermore, when the deaccented utterances were further divided into those ending in function words and those ending in given information, it was seen that L1 Brazilian Portuguese learners of English manifested higher awareness about nuclear stress assignment in utterances ending in function words.

One of the interesting findings of the study was the fact that L1 Brazilian Portuguese speakers manifested higher awareness about English nuclear stress assignment in deaccented utterances than in the unaccusative utterances. This finding parallels Nava and Zubizarreta's $(2008,2010)$ previous research conducted with L1 Spanish EFL learners who have been shown to acquire the Anaphoric Deaccenting Rule earlier than the Germanic Nuclear Stress Rule. The authors suggest that it is easier to acquire a new rule than to restructure an existing L1 rule to fit the L2 principles. Nevertheless, in the present study, the native English speakers were also found to perform significantly better in the deaccented trials than in the unaccusative trials (cf. 90-70\%). As native speakers manifested the same behavior as the language learners, the results cannot be attributed solely on differences between restructuring and acquisition of rules. Further studies are required to determine why appropriate nuclear stress assignment appears to be easier in deaccented utterances than in unaccusative ones, but a possible reason lies in the frequency of occurrence of these items. Unaccusative constructions are formed by a small number of verbs and the SV sentence structure occurs in the input with less frequency than the SVO pattern.

Contrary to the initial predictions, L1 Brazilian Portuguese speakers were not found to perform better in deaccented trials presenting given information than in deaccented trials ending in function words. It was hypothesized that L1 Brazilian Portuguese speakers might benefit 
from L1 focal stress assignment and transfer this strategy into L2 nuclear stress assignment in utterances presenting given information. However, the L1 Brazilian Portuguese EFL learners were shown to have higher awareness about English nuclear stress in utterances ending in function words than in utterances ending in given information (cf. 76-52\%). This finding suggests, on the one hand, that as function words are not deaccented in Brazilian Portuguese, the L1 Brazilian Portuguese participants of the study had acquired real awareness about English nuclear stress movement in this context, which was not traceable to L1 transfer. On the other hand, we might ask why the acquisition of target-like nuclear stress assignment was easier in the case of functional categories. A similar finding was made with L1 Spanish learners of English in a study by Nava and Zubizarreta (2010). The authors suggest that as accenting function words follows strict rules (strong and weak forms) which can be learnt, their acquisition is easier. On the contrary, deaccenting given information is acquired with more difficulty as it is context dependent and thus cannot be memorized.

Overall, the findings of the study indicate that L1 Brazilian Portuguese EFL learners' awareness about English nuclear stress assignment was deficient. Whereas awareness had been acquired about assigning nuclear stress in utterances ending in functional categories, no awareness, or very little awareness, had been acquired about assigning nuclear stress in unaccusative utterances or in utterances ending in given information. These results confirm previous research indicating that acquiring target-like nuclear stress assignment is challenging even for advanced L2 learners (ZUBIZARRETA; NAVA, 2011).

As non-target-like nuclear stress assignment is likely to lead into communication breakdowns, fostering language learners' awareness about L2 nuclear stress rules is crucial. It is likely that regular L2 input is not enough to make the principles governing nuclear stress assignment salient enough to be noticed, as even advanced language learners, who presumably have been extensively exposed to the target language, have not acquired them. Furthermore, previous studies with L2 prosodic awareness suggest that higher prosodic awareness is related to more target-like L2 perception and production, making its fostering a priority in the foreign language classroom (KENNEDY; BLANCHET, 2014; KENNEDY et al., 2014; KENNEDY; TROFIMOVICH, 2010).

In order to increase language learners' awareness, instructors are required to bring the principles governing nuclear stress assignment 
into the learners' attention through the employment of consciousness raising activities ${ }^{6}$. It has been shown that explicit prosody training and the employment of activities designed to raise learners' awareness about L2 prosody benefit learners' prosodic acquisition and the development of prosodic awareness (MITROFANOVA, 2012; RAMÍREZ VERDUGO, 2006; SAITO; WU, 2014). More studies concerning L2 prosodic awareness, and more specifically language learners' awareness about L2 nuclear stress assignment, are required in order to understand the complex phenomena governing L2 speech behavior. On the light of the results of the present study, introducing and increasing explicit L2 prosody teaching in the Brazilian EFL classroom is necessary for the achievement of more target-like L2 perception and production.

\section{Acknowledgements}

The author wishes to thank Dr. Joan Carles Mora (University of Barcelona) under whose orientation the research described in this manuscript was conducted.

\section{References}

ALVES, U. K.; ZIMMER, M.C. Percepção e produção dos padrões de vot do inglês por aprendizes brasileiros: $\mathrm{O}$ papel de múltiplas pistas acústicas sob uma perspectiva dinâmica. Alfa, São Paulo, v. 59, n.1, p. 157-180, 2015. https://doi.org/10.1590/1981-5794-1502-7.

CRISTÓFARO SILVA, T.; CAMARGOS, M.A. Conhecimento fonológico e apropriação de róticos em inglês L2 por falantes nativos de português brasileiro. Ilha do Desterro, Florianópolis, v. 69, n.1, p. 49-60, 2016. https://doi.org/10.5007/2175-8026.2016v69n1p49.

DEFIOR, S.; GUTIÉRREZ-PALMA, N.; CANO-MARÍN, M.J. Prosodic awareness skills and literacy acquisition in Spanish. Journal of Psycholinguistic Research, v. 41, n. 4, p. 285-294, 2012. https://doi. org/10.1007/s10936-011-9192-0.

FERNANDES, F. R. Ordem, focalização e preenchimento em português: Sintaxe e prosódia. 2007. Dissertation (Doctoral) - Campinas State University, Campinas, 2007.

\footnotetext{
${ }^{6}$ Any activity that would increase the noticing of L2 nuclear stress assignment, such as, explicit prosody teaching or recording and comparing own intonation to native speaker intonation auditorily and visually through waveforms, for example
} 
FERNANDES SVARTMAN, F. R. A distinção foco/tópico em tzotzil, jakaltek, tembé, xavante, português brasileiro e português europeu. Revista de Estudos da Linguagem, Belo Horizonte, v. 16, n. 2, p. 55-87, 2008.

FORSTER, K. I.; FORSTER, J.C. DMDX (Version 4.0.6.0). Computer software. 2012. Retrieved from: <http://www.u.arizona.edu/ jforster/ dmdx.htm>. Accessed: $11^{\text {th }}$ May 2016.

FROTA, S.; CRUZ, M.; SVARTMAN, F. R.; COLLISCHONN, G.; FONSECA, A.; SERRA, C.; OLIVEIRA, P.; VIGÁRIO, M. Intonational variation in Portuguese: European and Brazilian varieties. In: FROTA, S.; PRIETO, P. (Ed.). Intonational Variation in Romance. Oxford: Oxford University Press, 2015. p. 235-283. https://doi.org/10.1093/acprof: oso/9780199685332.003.0007.

GOODMAN, I.; LIBENSON, A.; WADE-WOOLLEY, L. Sensitivity to linguistic stress, phonological awareness and early reading ability in preschoolers. Journal of Research in Reading, v. 33, n. 2, p. 113-127, 2010. https://doi.org/10.1111/j.1467-9817.2009.01423.x.

GUTIÉRREZ-PALMA, N.; PALMA REYES, A. Stress sensitivity and reading performance in Spanish: A study with children. Journal of Research in Reading, v. 30, n. 2, p. 157-168, 2007. https://doi. org/10.1111/j.1467-9817.2007.00339.x.

HOLLIMAN, A.; WOOD, C.; SHEEHY, K. Sensitivity to speech rhythm explains individual differences in reading ability independently of phonological awareness. British Journal of Developmental Psychology, v. 26, n. 3, p. 357-367, 2008. https://doi.org/10.1348/026151007X241623.

JILKA, M. Testing the contribution of prosody to the perception of foreign accent. In: Proceedings of New Sounds (4th International Symposium on the Acquisition of Second Language Speech), 2000, Amsterdam, p. 199 -207.

JOHNSON, E.; JUSCZYK, P. Word segmentation by 8-month-olds: When speech cues count more than statistics. Journal of Memory and Language, v. 44, n. 4, p. 548-567, 2001. https://doi.org/10.1006/ jmla.2000.2755.

KENNEDY, S. Exploring the relationship between language awareness and second language use. TESOL Quarterly, v. 46, n. 2, p. 398-408, 2012. https://doi.org/10.1002/tesq. 24. 
KENNEDY, S.; BLANCHET, J. Language awareness and perception of connected speech in second language. Language Awareness, v. 23, n. 1-2, p. 92-106, 2014. https://doi.org/10.1080/09658416.2013.863904. KENNEDY, S.; BLANCHET, J.; TROFIMOVICH, P. Learner pronunciation, awareness, and instruction in French as a second language. Foreign Language Annals, v. 47, n. 1, p. 79-96, 2014. https://doi.org/10.1111/flan.12066.

KENNEDY, S.; TROFIMOVICH, P. Language awareness and second language pronunciation: a classroom study. Language Awareness, v. 19, n. 3, p. 171-185, 2010. https://doi.org/10.1080/09658416.2010.486439. KIVISTÖ-DE SOUZA, H. Phonological awareness and pronunciation in a second language. 2015. Dissertation (Doctoral) - University of Barcelona, Barcelona, Spain, 2015.

KLUGE., D. Effects of preceding vowel in the perception of the English nasal consonants $/ \mathrm{m}, \mathrm{n} /$ in word-final position by Brazilian EFL learners. Diadorim, Rio de Janeiro, v. 12, n. 1, p. 167-173, 2012.

LANCE, D.; SWANSON, L.; PETERSON, H. A validity study of an implicit phonological awareness paradigm. Journal of Speech, Language \& Hearing Research, v. 40, n. 5, p. 1002-1010, 1997. https://doi. org/10.1044/jslhr.4005.1002.

MEARA, P. M. X_Lex: The Swansea vocabulary levels test (Version 2.05.) Computer software. Swansea: Lognostics, 2005.

MILTON, J. The development of vocabulary breadth across the CEFR levels: A common basis for the elaboration of language syllabuses, curriculum guidelines, examinations, and textbooks across Europe. In: BARTNING, I.; MARTIN, M.; VEDDER, I. (Ed.). Eurosla Monographs Series 1: Communicative Proficiency and Linguistic Development, 2000. p. 211-232). Retrieved from: <http://eurosla.org/monographs/EM01/ EM01 tot.pdf. $>$. Accessed: 11 $1^{\text {th }}$ May, 2016.

MITROFANOVA, Y. Raising EFL students' awareness of English intonation functioning. Language Awareness, v. 21, n. 3, p. 279-291, 2012.

MORAES, J. A. Intonation in Brazilian Portuguese. In: HIRST, D.; DI CRISTO, A. (Ed.). Intonation systems: A survey of twenty languages. Cambridge: Cambridge University Press, 1998. p. 179-194. https://doi. org/10.1080/09658416.2011.609621. 
MORAES, J. A. Intonational phonology of Brazilian Portuguese. Poster session presented at the Workshop on Intonational Phonology, 16th International Congress of Phonetic Sciences, 2007, Saarbrücken.

NAVA, E. Prosody in L2 acquisition. In: Proceedings of the 9th Generative Approaches to Second Language Acquisition Conference (GASLA) 2007, Somerville, MA: Cascadilla Proceedings Project, 2008. p. 155-164.

NAVA, E.; ZUBIZARRETA, M. L. Prosodic transfer in L2 speech: Evidence from phrasal prominence and rhythm. In: BARBOSA, P.; MADUREIRA, S.; REIS, C. (Ed.). Proceedings of Speech Prosody 2008, Campinas, Brazil. Retrieved from: $<$ http://sprosig.isle.illinois.edu/ sp2008/papers/id041.pdf>. Accessed: $11^{\text {th }}$ May, 2016.

NAVA, E.; ZUBIZARRETA, M. L. Deconstructing the nuclear stress algorithm: Evidence from second language speech. In: ERTESCHIKSHIR, N.; ROCHMAN, L. (Ed.). The Sound Patterns of Syntax. Oxford: Oxford University Press, 2010. p. 291-317.

PASSARELLA DOS REIS, L.; GONÇALVES, A.R.; SILVEIRA, R. Perception of intonational patterns and speaker's intentionality in English yes-no questions produced by Brazilians. Revista de Estudos da Linguagem, Belo Horizonte, v. 24, n. 1, p. 65-97, 2016. https://doi. org/10.17851/2237-2083.24.1.65-97.

RAMÍREZ VERDUGO, D. A study of intonation awareness and learning in non-native speakers of English. Language Awareness, v. 15, n. 3, p. 141-159, 2006. https://doi.org/10.2167/la404.0.

RAUBER, A. Perception and production of English vowels by Brazilian EFL speakers. 2006. Dissertation (Doctoral) - Federal University of Santa Catarina, Florianópolis, 2006.

SAITO, K.; WU, X. Communicative focus on form and second language suprasegmental learning: Teaching Cantonese learners to perceive Mandarin tones. Studies in Second Language Acquisition, v. 36, n. 4, p. 647-680, 2014. https://doi.org/10.1017/S0272263114000114.

SILVEIRA, R. PL2 production of English word-final consonants: The role of orthography and learner profile variables. Trabalhos em Linguística Aplicada, São Paulo, v. 51, n. 1, p. 13-34, 2012. https://doi.org/10.1590/ S0103-18132012000100002. 
TARONE, E.; BIGELOW, M. Impact of literacy on oral language processing: Implications for second language acquisition research. Annual Review of Applied Linguistics, v. 25, n. 1, p. 77-97, 2005. https://doi.org/10.1017/s0267190505000048.

TENANI, L. Domínios prosódicos no português do Brasil: Implicações para a prosódia e para a aplicação de processos fonológicos. 2002. Dissertation (Doctoral) - Campinas State University, Campinas, 2002.

TROFIMOVICH, P.; BAKER, W. Learning second language suprasegmentals: Effect of L2 experience on prosody and fluency characteristics of L2 speech. Studies in Second Language Acquisition, v. 28, n. 1, p. 1-30, 2006. https://doi.org/10.1017/S0272263106060013.

TRUCKENBRODT, H.; SANDALO, F.; ABAURRE, M. B. Elements of Brazilian Portuguese intonation. Journal of Portuguese Linguistics, v. 8, n. 1, p. 77- 115, 2008.

WELLS, J. C. English intonation: An introduction. $5^{\text {th }}$ ed. Cambridge: Cambridge University Press, 2006.

WHALLEY, K.; HANSEN, J. The role of prosodic sensitivity in children's reading development. Journal of Research in Reading, v. 29, n. 3, p. 288-303, 2006. https://doi.org/10.1111/j.1467-9817.2006.00309.x.

WOOD, C.; TERRELL, C. Poor readers' ability to detect speech rhythm and perceive rapid speech. British Journal of Developmental Psychology, v. 16, n. 3 p. 397-413, 1998. https://doi.org/10.1111/j.2044-835X.1998. tb00760.x.

ZUBIZARRETA, M. L. Prosody, focus, and word order. Linguistic Inquiry Monograph, 33. Cambridge, MA: MIT Press, 1998.

ZUBIZARRETA, M. L.; NAVA, E. Encoding discourse-based meaning: Prosody vs. syntax: Implications for second language acquisition. Lingua, v. 121, n. 4, p. 652-669, 2011. https://doi.org/10.1016/j. lingua.2010.06.013.

ZUBIZARRETA, M. L.; VERGNAUD, J. R. Phrasal stress, focus and syntax. In: EVERAERT, M.; van RIEMSDIJK, H. (Ed.). The Blackwell companion to syntax. Malden, MA: Blackwell, 2005. p. 522-568. 